\title{
Notes on the vocalizations of Yellow-bellied Prinia (Prinia flaviventris)
}

Peter Boesman

In the following we briefly analyze and compare voice of the different races of Yellow-bellied Prinia (Prinia flaviventris). We also try to quantify the extent of any vocal differences using the criteria proposed by Tobias et al. (2010), as a support for taxonomic review. We have made use of sound recordings available on-line from Xeno Canto (XC).

Song of all races is a short lively phrase descending in pitch. Some examples from west to east:

Pakistan (sindiana)

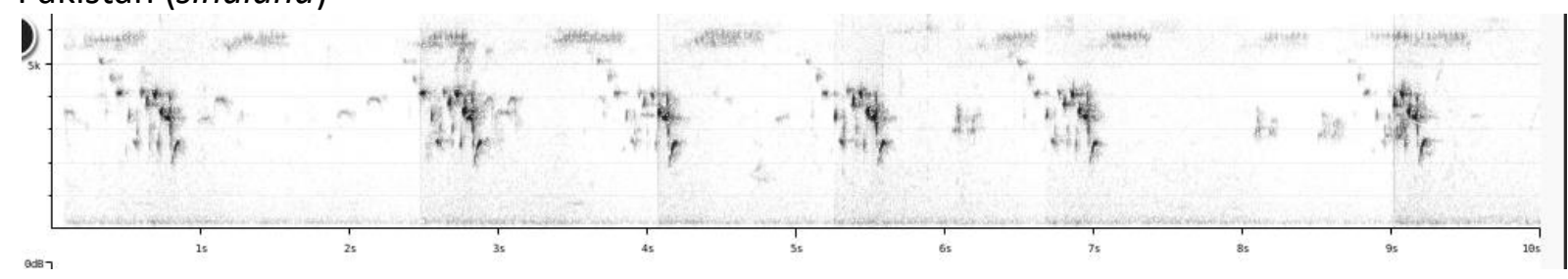

$\mathrm{N}$ India (flaviventris)

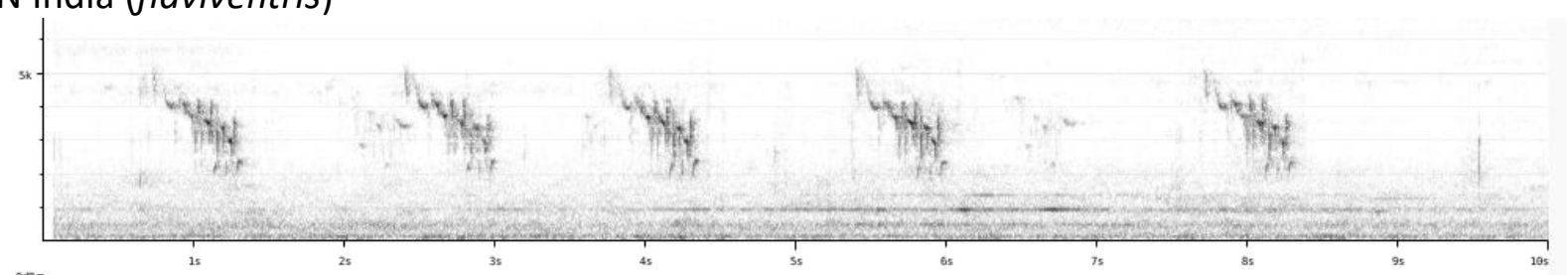

Peninsular Malaysia (rafflesi)

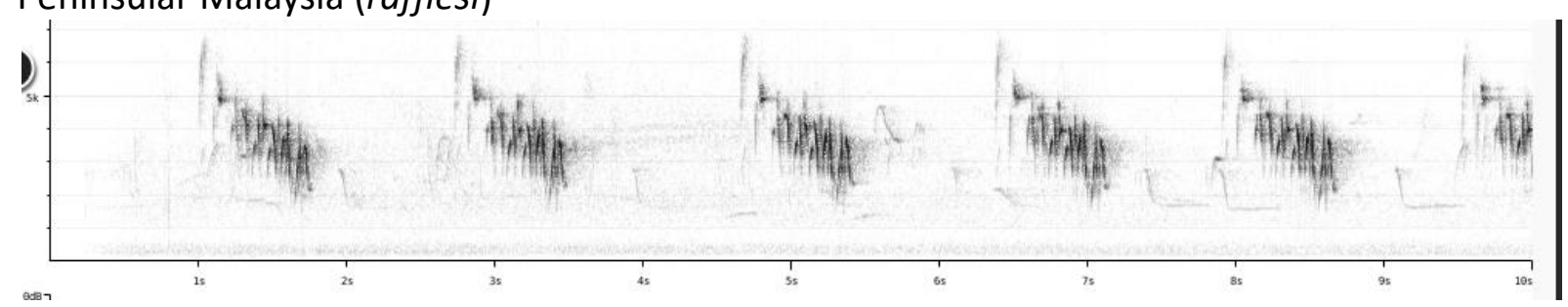

Indonesia (rafflesi)

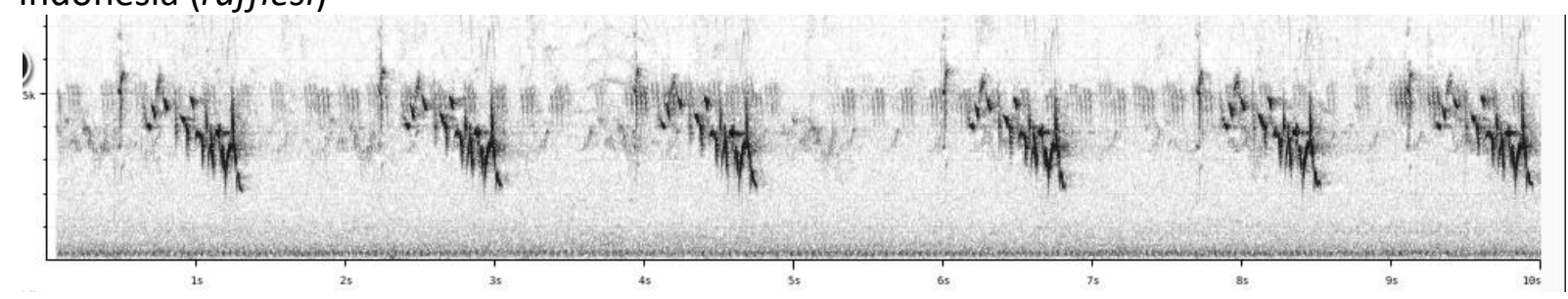

Borneo (latrunculus)

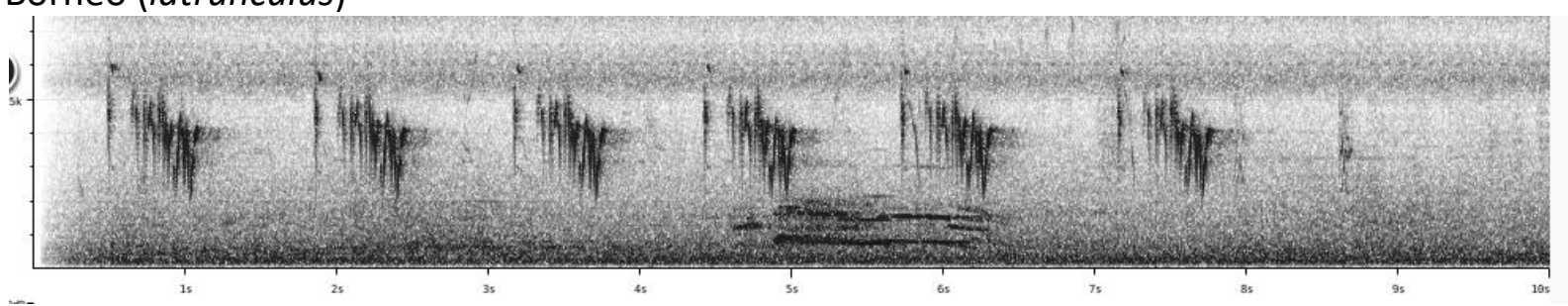




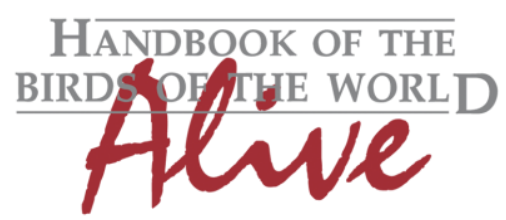

\section{ORNITHOLOGICAL NOTES}

Cambodia (delacouri)

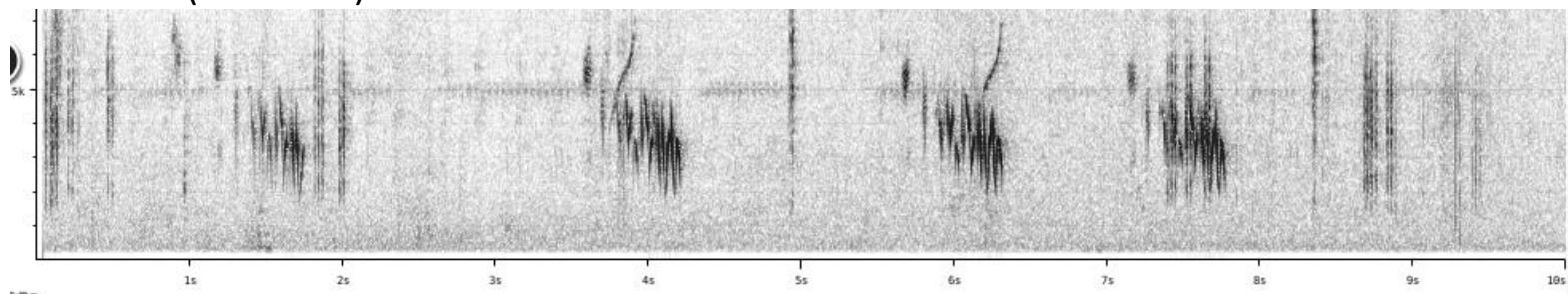

NE Vietnam (sonitans)

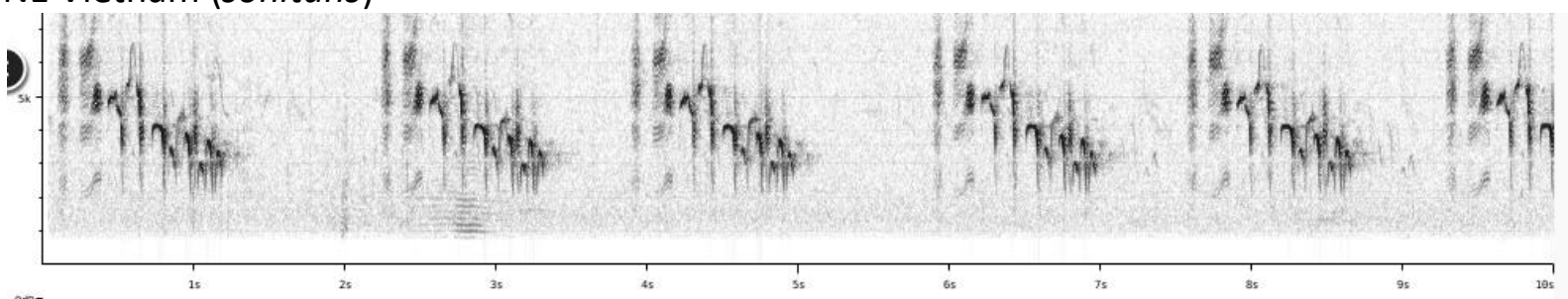

S China (sonitans)

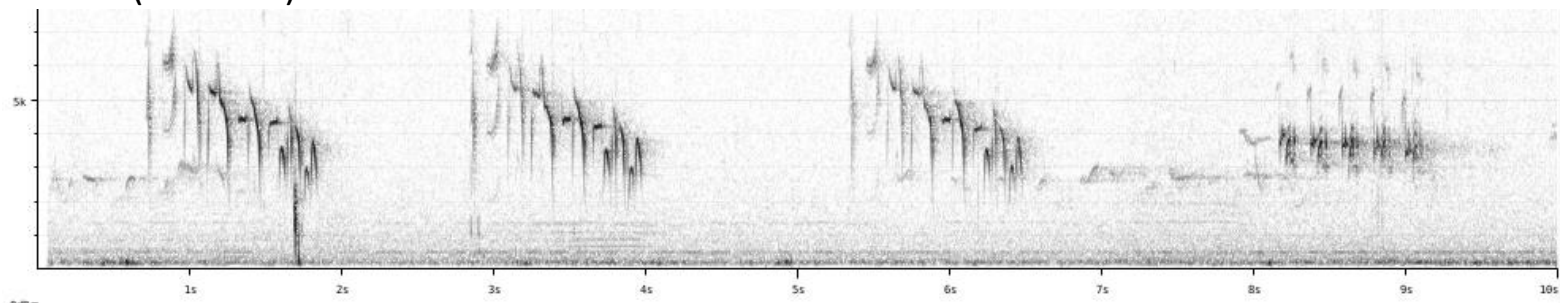

E China (sonitans)

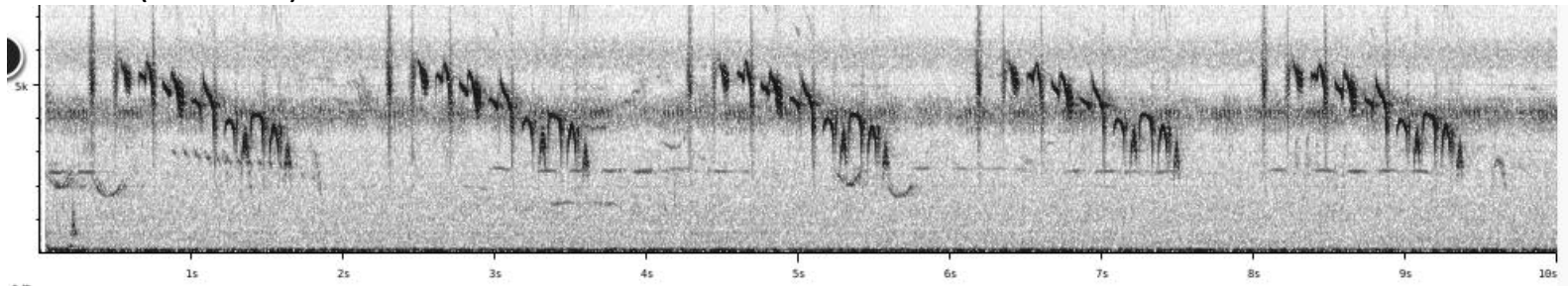

Taiwan (sonitans)

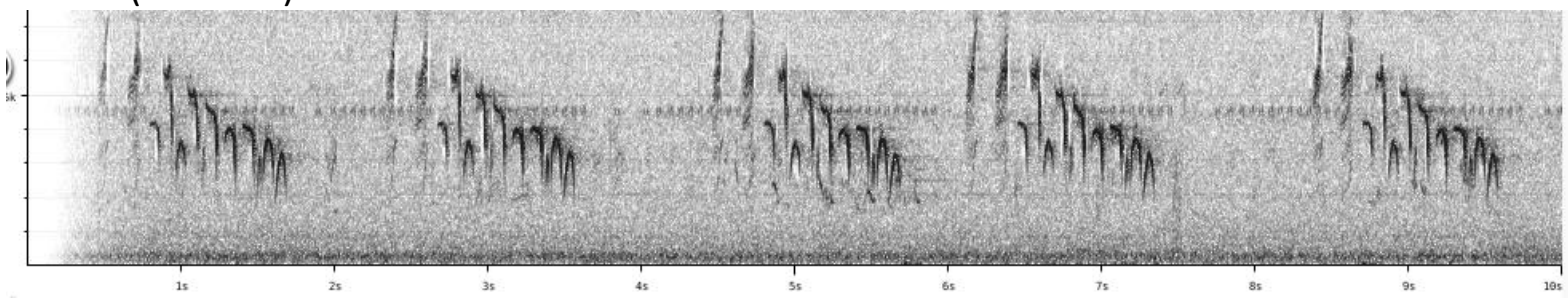

There are slight regional differences, which may be larger than individual differences within each subspecies. There is however no clear vocal difference between sonitans/latrunculus as one combined group (denominated as E group in HBW Alive: Madge et al. 2016) and the rest.

On the contrary, there IS a vocal difference between sonitans (NE Vietnam, S and E China, Taiwan) and the rest: the former has a clearly longer song phrase (phrase length $1.1-1.5 \mathrm{~s}$ vs. $0.5-0.9 \mathrm{~s}$, score $2-3$ ).

To a lesser extent, sindiana stands vocally apart as it has a much more eerie tinkling song compared to other races (a single recording from $\mathrm{N}$ India is however somewhat intermediate). This could tentatively be given a score of 1-2. 

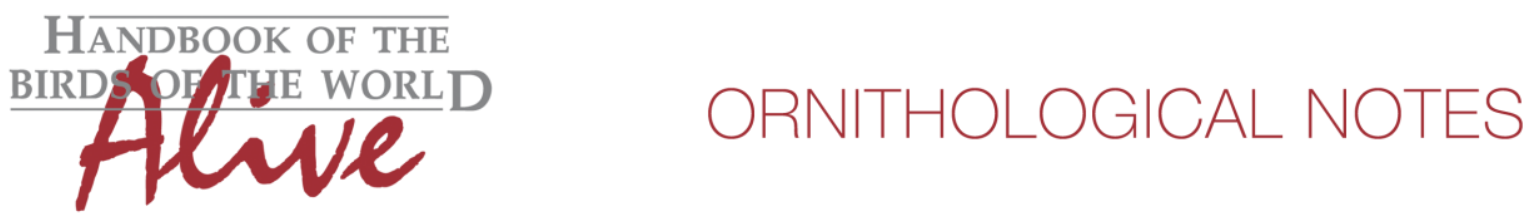

As for latrunculus, vocal differences with neighbouring rafflesi are subtle: it would seem that one can at least separate them with $90 \%$ confidence as latrunculus has a well-spaced first note which is quite emphasized, versus a first note that is rather a silent start of the downslurred song phrase in rafflesi. Given there is some slight overlap, this could be given a score of 1.

This note was finalized on 16th February 2016, using sound recordings available on-line at that moment. We would like to thank in particular the many sound recordists who placed their recordings for this species on XC.

\section{References}

Madge, S. (2016). Yellow-bellied Prinia (Prinia flaviventris). In: del Hoyo, J., Elliott, A., Sargatal, J., Christie, D.A. \& de Juana, E. (eds.). Handbook of the Birds of the World Alive. Lynx Edicions, Barcelona. (retrieved from http://www.hbw.com/node/58590 on 16 February 2016).

Tobias, J.A., Seddon, N., Spottiswoode, C.N., Pilgrim, J.D., Fishpool, L.D.C. \& Collar, N.J. (2010). Quantitative criteria for species delimitation. Ibis 152(4): 724-746.

\section{Recommended citation}

Boesman, P. (2016). Notes on the vocalizations of Yellow-bellied Prinia (Prinia flaviventris). HBW Alive Ornithological Note 228. In: Handbook of the Birds of the World Alive. Lynx Edicions, Barcelona. (retrieved from http://www.hbw.com/node/932189 on 28 September 2016). 